\title{
Interviewing the Experts: Student Produced Podcast
}

\author{
Gary R. Armstrong and \\ Joanne M. Tucker \\ Shippensburg University, \\ Shippensburg, Pennsylvania, USA
}

grarms@ship.edu; imtuck@ship.edu

\author{
Victor J. Massad \\ Kutztown University, \\ Kutztown, Pennsylvania, \\ USA
}

massad@kutztown.edu

\section{Executive Summary}

Classroom instruction continues to change dramatically with new technology and pedagogy. Faculty aspire to develop innovative programs and creative education while seeking effective teaching strategies that capitalize on emerging technology and invoke student interest and involvement. Research shows that student involvement, hands-on projects, and teamwork are successful pedagogical approaches (Kayes, Kayes, \& Kolb, 2005; McKeachie 1994; Passman 2001).

This paper describes a creative project for students that showcases technology and student involvement. Additionally, the assignment is consistent with the seven principles for good practice in higher education (Chickering \& Gamson, 1987) and provides desired outcomes to business education such as business fundamentals, critical thinking, teamwork, and technology skills.

Students prepare a team-based research presentation on a topic that incorporates a student produced podcast. Students produce and share a podcast in which they interview an expert or knowledgeable individual in the research topic area. By producing podcasts, students have the opportunity to research and analyze information, communicate effectively, and incorporate the opinions of experts in a cutting-edge way. Producing and comparing their own work to that of others can give students a valuable perspective on their own abilities and inspire them to try new ideas or techniques.

Software programs and computers make it easier to record and edit audio and video programs than in the past. During the course of the project, students are exposed to Audacity, Windows Movie Maker, Visio, FreeMind, new search engines, HTML and RSS code, FTP, and the operation of digital and audio recorders. The instructor has the option of providing access to the podcast to a course management system such as Blackboard; making each team's podcast available for campus consumption by uploading the podcast to a restricted website; or providing unrestricted access by posting the podcast to iTunes or similar podcast subscription service.

Material published as part of this publication, either on-line or in print, is copyrighted by the Informing Science Institute. Permission to make digital or paper copy of part or all of these works for personal or classroom use is granted without fee provided that the copies are not made or distributed for profit or commercial advantage AND that copies 1) bear this notice in full and 2) give the full citation on the first page. It is permissible to abstract these works so long as credit is given. To copy in all other cases or to republish or to post on a server or to redistribute to lists requires specific permission and payment of a fee. Contact Publisher@,InformingScience.org to request redistribution permission.
We utilized an evaluation questionnaire to assess the effectiveness of the project. From the students' perspective, the project was very effective in meeting educational objectives. The design of the project utilizes the seven principles for good practice in higher education, and skills students need to produce the podcast are consistent with desired learning outcomes. Student produced podcasts 
Interviewing the Experts

provide the instructor an opportunity to build a library of podcasts, which then can be integrated into future classes. The result is a win-win opportunity for student and faculty alike.

Keywords: podcast, student collaboration, technology, MIS curriculum, business education

\section{Introduction}

Classroom instruction continues to change dramatically as faculty seek effective teaching strategies that capitalize on new technology and invoke student interest and involvement. Research shows that student involvement, hands-on projects and teamwork are successful pedagogical approaches (Kayes, Kayes, \& Kolb, 2005; McKeachie 1994; Passman 2001).

There are any number of ways to promote student involvement in the classroom. Many faculty use various case analyses, simulations, group project reports, games, and other approaches to encourage student participation and learning. Technology is also making its way into the classroom in different ways. Remote controls, otherwise known as student response systems or clickers, are just one example of new technologies that have recently infiltrated college classrooms. Videostreaming classrooms, wikis, blogs, and course delivery systems such as Blackboard are but a few of the technological tactics in play.

This paper describes a class project for students that showcases student involvement and technology while providing an avenue for students to practice their skills in analyzing information and communicating ideas. Students in an introductory management information systems (MIS) course prepare a team-based research presentation on a topic that incorporates a student produced podcast. Typically, a podcast represents an interview with an expert or knowledgeable individual in the research topic area. Students manage the research project, from selection of the topic to uploading their podcast to iTunes or other locations. The assignment provides a creative solution for students to disseminate information and provides a way to develop their professional communication and literacy skills. When students produce a podcast, it develops their skills in teamwork, communication, organization, technical literacy, and planning, as well as the ability to research and write up the podcast topic and script. The design of the class project adheres to the seven principles of undergraduate education (Chickering \& Gamson, 1987) and provides desired learning outcomes to the MIS course such as MIS business fundamentals, critical thinking, teamwork, and technology skills.

\section{Literature Survey}

A format for classroom instruction is The Seven Principles for Good Practice in Undergraduate Education (Chickering \& Gamson, 1991). The Seven Principles, supported by research, are based on an underlying view of education as active, cooperative, and demanding. The principles set forth suggest how teachers should convey subject matter, not what subject matter should to present, as good practice in undergraduate education. The Seven Principles can serve as a framework for engaging students in the learning process of researching, writing, and discussing a variety of contemporary business issues (Henninger \& Hurlbert, 2006; Page \& Mukherjee, 2000). Each principle accentuates and promotes resource-based and active learning while respecting diverse talents and learning styles.

According to the Chickering \& Gamson (1991) good practice in undergraduate education: (1) encourages contact between students and faculty, (2) develops reciprocity and cooperation among students, (3) encourages active learning, (4) gives prompt feedback, (5) emphasizes time on task, (6) communicates high expectations, and (7) respects diverse talents and different ways of learning. The principles were derived without reference to technological tools used in the student learning process. Only a few studies have focused on how technology such as the Internet may facilitate the application of these principles (Newlin \& Wang, 2002, Ritter \& Lernke, 2000). One 
study analyzed the use of faculty created podcasts in relation to the Seven Principles (Fernandez, Simo, \& Sallan, 2009).

Existing literature shows the primary use of podcasting in academia is to disseminate lectures and other course related information. Although the use of audio and video content is not new in education, podcasting adds a new modality of learning. Major universities such as University of California - Berkeley, Princeton University, and Stanford University have implemented podcast course delivery at an institutional level. Apple hosts iTunes U, a free service for colleges and universities that provides easy access to audio and video content including lectures and interviews, using the same technology as the commercial iTunes Music Store. Higher Education Podcast Repository (http://ed-cast.org/) is also a large repository of podcasts in education.

While research exists that considers podcasts created at the institutional level, there is a dearth of research regarding student produced podcasts. The authors of the present paper agree with other researchers (see, for example, Lee, McLoughlin, \& Chan; 2008) that "the true potential of podcasting technology lies in its knowledge-creation value, and its use as a vehicle for disseminating learner-generated content." This view is shared by Miller (2006) as well as Atkinson (2006), the latter of who believes that podcasting has limited impact as a mere method of distribution and that "the emerging developmental and research direction seems ... to be learning through creating podcasts and similar, in contrast to learning from podcasts."

This paper describes a student produced podcasting assignment that in design follows the Seven Principles for good practice in undergraduate education. Students learn through creating podcasts and in the process achieve desired learning outcomes for the course. The course and podcasting assignment are described next.

\section{Course and Class Project Overview}

Most AACSB accredited business schools offer a core management information systems (MIS) course. Common teaching methodologies for an introductory MIS courses include a hands-on technical assignment and team business project (Wang, 2007). In our introductory (MIS) course, we designed a class project that combines these two methodologies. Student teams prepare a research presentation on a topic that incorporates a student produced podcast. As mentioned earlier, podcasting has become increasingly familiar as a method of sharing information. Podcasts are generally considered audio MP3 digital files or video podcasts, sometimes referred to as "VLogs." Most students are embracing this trendy technology of podcasting through their use of MP3 players and iPods. Since students are already familiar with hand-held MP3 technology, integrating podcasts with curricular content is generally easily accepted by students. For the MIS course, four desired learning outcomes are: (1) student understanding of MIS fundamentals; (2) development of analytical and critical thinking; (3) improvement of ethical, interpersonal, communication, and team skills; and (4) instillation of technology skills. The class project, like other requirements of the course, should support these desired learning outcomes.

In creating a podcast as part of their research project presentation, each team has the option of producing either a video podcast or an audio podcast. The podcast is a way of presenting taped interviews with experts; however, podcasts may also be used to document field trips, observations, notes, and other relevant information. The instructor has the option of (1) providing access to the podcast to only those enrolled in the instructor's course by uploading the podcast to a course management system such as Blackboard; (2) making each team's podcast available for campus consumption by uploading the podcast to a personal but restricted website; or (3) providing unrestricted access by posting the podcast to iTunes, Yahoo! or similar podcast subscription service. 


\section{Podcast Basics}

The New Oxford American Dictionary defines "podcast" as a digital recording of a radio broadcast or similar program, made available on the Internet for downloading to a personal audio player ("Podcast," 2005). A podcast is a digital audio or video file that is created, shared, and heard.

Whether one chooses to produce an audio versus a video podcast presents a set of advantages and disadvantages. When producing a video podcast, lighting and camera angles are considerations that are absent in producing audio podcasts. Video files are generally larger than audio files, thereby promoting potential storage and handling issues. Video podcasts have the potential to communicate more information than audio podcasts because they appeal to the senses of both sight and sound. Creating a video podcast also requires a video camcorder or similar device for recording and editing software such as Windows MovieMaker.

There are advantages to producing an audio podcast instead of a video podcast. One advantage is that it encourages students to communicate without dealing with lighting and camera angle issues. These issues may detract rather than add to the communicative value for a student's learning experience. In addition, it is less time-consuming to edit an audio podcast than a video podcast. Since audio podcasts are inherently easier to produce than videos, some educators contend audio podcasts can help students focus more on a message's content and its effective delivery (Sterne, 2005). Audio podcasts require a digital recorder and audio editing software such as Audacity. In the past, all student teams have chosen to produce a video podcast in lieu of an audio podcast.

Software and instructions are easily accessible to support the production of either an audio or video podcast. Software, such as Audacity and Windows Movie Maker, are available for free download and use. Audacity online tutorials are free and cover all aspects of creating a podcast including recording, editing basics, importing music, and exporting a podcast as an MP3 file. Windows Movie Maker is now part of Windows Vista in both the Home and Ultimate versions. Free online tutorials are also available for using Windows Movie Maker including editing basics and exporting features (See Appendix A: Software Sources and Sites for downloads and tutorials).

\section{Project Management and Content}

In selecting and presenting their research topic each team completes several steps. The first step is to select a research topic by perusing the Internet, library, and other sources such as domainspecific search engines available at http://searchenginewatch.com. Research topics must include some aspect of technology or related application. For example, past research topics have been technology and campus security systems, technology and campus career development center, and technology and stock market investments and MIS profession.

Once the research topic is approved the teams conduct several brainstorming sessions to identify specific research objectives and consider podcast ideas to support the research topic. Students graphically organize ideas and relate research objectives with FreeMind, a freeware mind mapping program. Mind mapping is increasingly being used in business, government, and education to brainstorm or to plan a project or presentation (Tucker, Armstrong, \& Massad, 2009). Figure 1, Project Mind Map, is an illustration of a mind map developed by the instructor to organize and relate objectives of the research project and podcast with students. The left side of Figure 1 displays organizational steps and objectives for selecting and presenting a research project. The right side of Figure 1 focuses on specific hardware/software components, conceptual and communication skills needed for producing audio or video podcasts. 


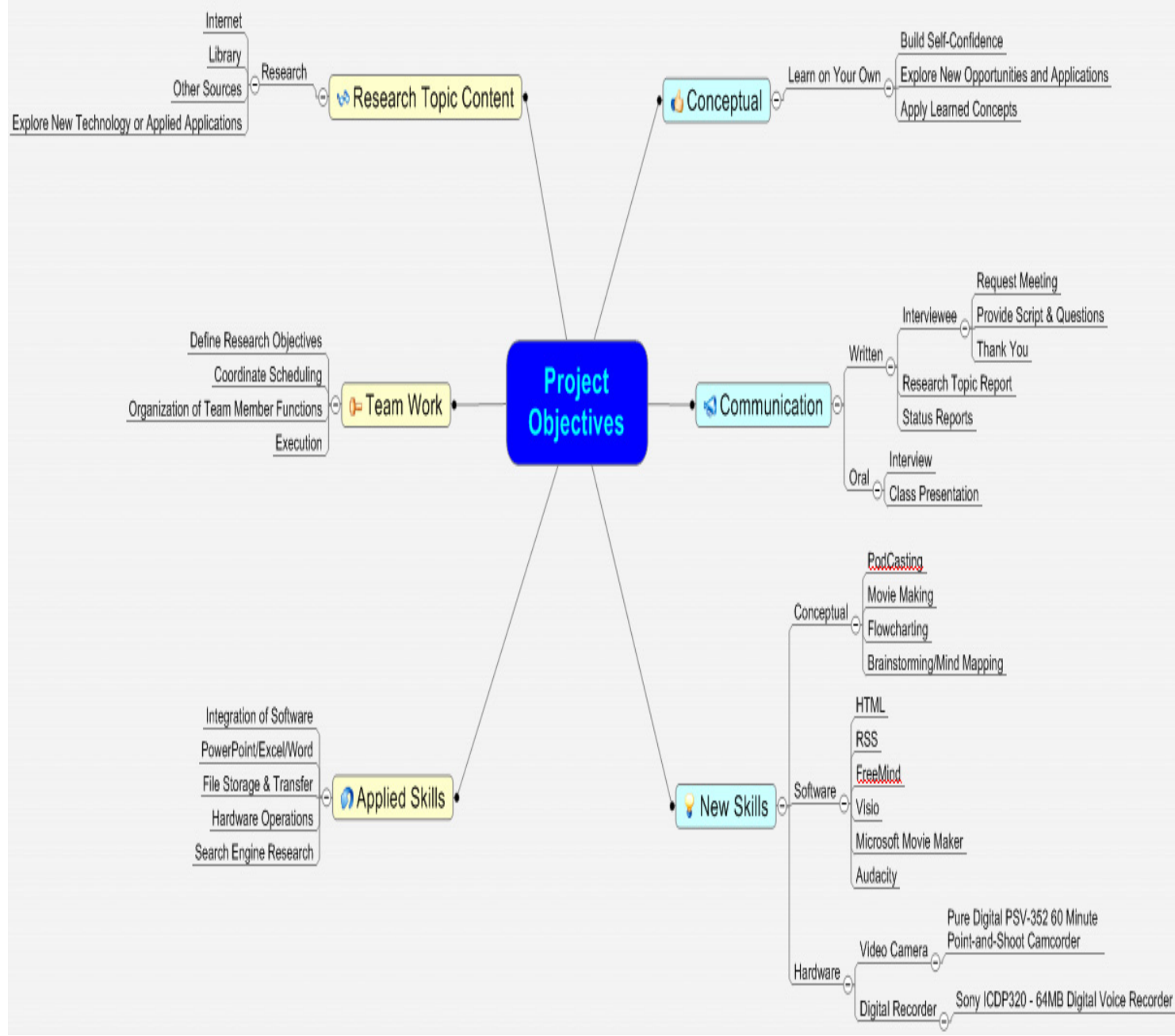

Figure 1: Project Mind Map

Teams define research objectives that serve as a guide in determining what questions will be addressed during the podcast interview with their chosen expert. Each team prepares a letter requesting a meeting with the expert and provides prepared questions to the interviewee. Students prepare a script which is reviewed and approved by the instructor. Each team follows up the interview with a "thank you" letter. To illustrate, one team's research topic was technology and stock investments. They prepared questions for a Senior Vice President of a local investments firm for a five to ten minute interview. The following are the questions and abbreviated responses from the Senior Vice President:

Question 1. What do you think makes your business successful?

Answer 1. ...the people I have around me. I have excellent staff of secretaries and partners and ...technology to keep up with the portfolios and how they are serving our clients. So, a combination of excellent people and technology is what makes our business successful...

Question 2. How does technology actually help?

Answer 2. ...we are tied into all the world markets technology helps through emails, communications like conference calls, Internet and monitoring business environment...

Question 3. What technology has helped you the most? 
Interviewing the Experts

Answer 3. ...I would say computer technology. I have been doing this for twenty-six years. Technology such as computers and software has allowed me to keep track and monitor so much more...

Question 4. Technology is changing every day. Do you think that helps or hurts in your business?

Answer 4. ... software is changing so quickly and so is the training out there ...you have to balance the benefits of the software and the training time that takes away time from the business .... so there is a trade-off ...

Question 5. The public and your clients have access to the Internet and stock information. How does that affect your business?

Answer 5. ...It helps me. The better my clients are informed and educated it makes my job easier from a communications standpoint. The downside is they are watching every move. "What is important is not timing in the market but time in the market." You have to live with the daily ups and downs. I think overall more informed clients are a plus...

Question 6. If you could invent one thing to help your job what would it be?

Answer 6. .... better understand of the software programs and what they can do...

Question 7. Other comments?

Answer 7. ...computer technology brings so much to the table... you must be willing to learn and retrain...

The university makes available portable digital recorders and video camcorders to the students for use during the interview meeting. Software, such as Audacity or Movie Maker, edits and adds background music to the recording. Students learn Audacity and MovieMaker without classroom instruction. This served to both demonstrate and reinforce their ability to master new software without an instructor's assistance - a necessary survival skill in today's environment. Upon completing their podcast, the instructor may choose for students to upload their podcasts to a course management system such as Blackboard, a restricted website; or for unrestricted access, to iTunes or similar podcast subscription service using Really Simple Syndication (RSS), HyperText Markup Language (HTML), and file transfer protocol (FTP).

Presenting their research to the class is the last step. Each team presents their published podcast, discusses the merit of their research, responds to questions, and provides a short discussion of lessons learned.

\section{Timeline}

Since our class consisted of eight teams of four students and we had limited number of audio recorders and video camcorders, we set up a schedule so that each team would have use of the video and audio equipment during their interview. Figure 2, Team Project Schedule, shows the timeline for teams to complete main steps in producing their podcast. 


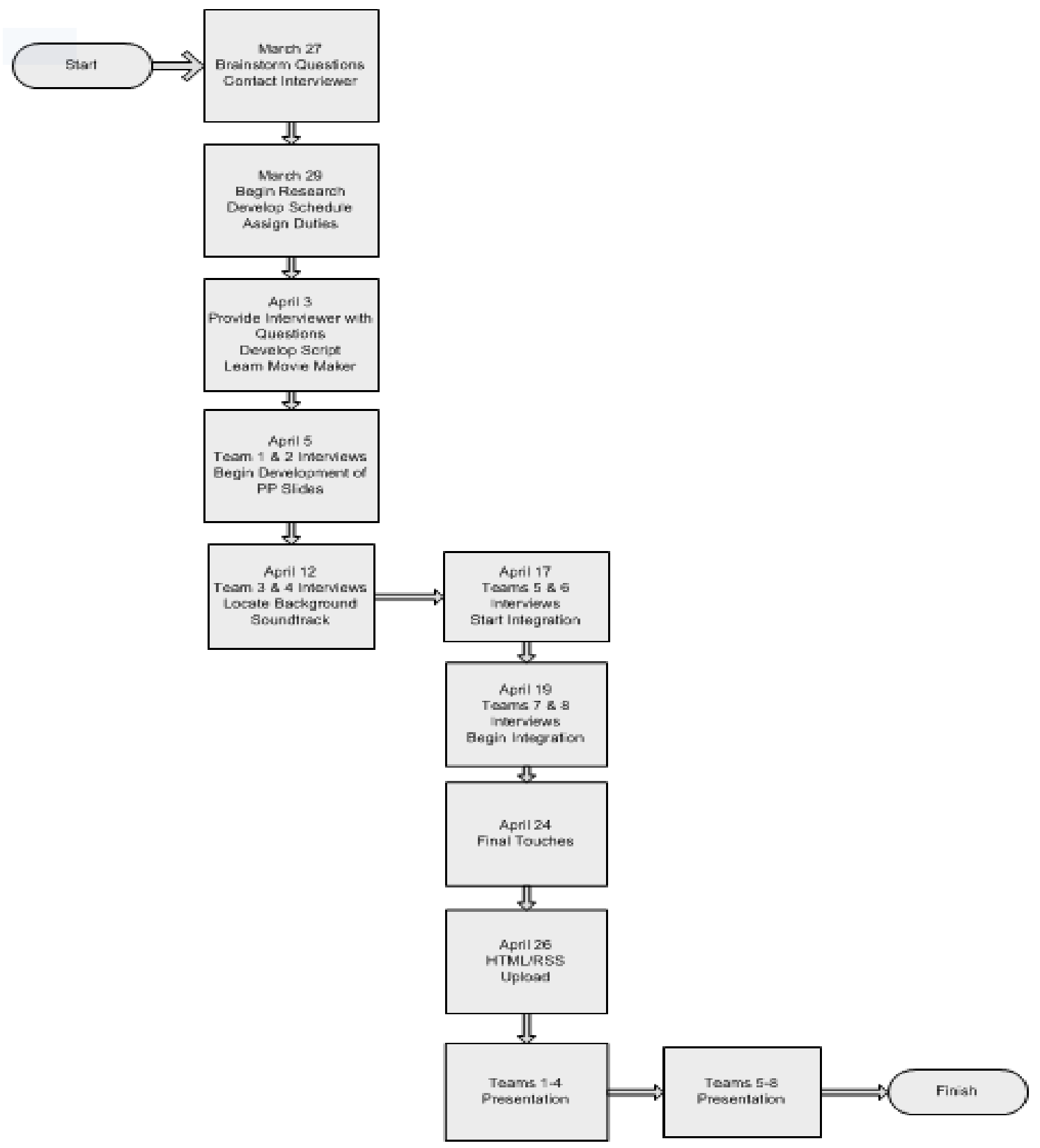

Figure 2: Team Project Schedule

FreeMind (mind-mapping) and Visio (flow-charting) are optional software students may use to help manage the research project and developing a project timeline. Other graphic-type software, such as Windows's Paint program, could also be used to expose students to the concept of flowcharting and process planning.

\section{Assessment}

To assess the effectiveness of the project and to enhance the learning experience for future students we utilized an evaluation questionnaire. The following learning objectives for the project were given to the students at the beginning of the semester. 
1. Integration of communication skills and knowledge

2. Encouraging cooperation between students in groups

3. Fostering creativity

4. Developing technology skills

5. Promoting development of literacy skills and confidence

6. Experiencing multi-media applications

7. Experiencing critical analysis of information

8. Developing self-reliance within new technology areas

From the students' perspective, the project was very effective in meeting the eight educational objectives. Student response to the evaluation questionnaire was very positive. Given at the end of the semester the questionnaire asked students to what degree (on a scale of 1 to 5 with 5 as very high) they felt the educational objectives were met. The modal response was " 5 " to six of the eight course objectives. Two course objectives (number 1 and 8 ) had a modal response of "4". Table 1, Student Evaluation - Project Meets Educational Objectives, provides modal and average scores for each objective.

\section{Table 1: Student Evaluation - Project Meets Educational Objectives}

$\begin{array}{lll}\text { Educational Objectives } & \text { Mode } & \text { Average } \\ \text { 1. Integration of communication skills and knowledge } & 4 & 4.0 \\ \text { 2. Encouraging cooperation between students in groups } & 5 & 3.7 \\ \text { 3. Fostering creativity } & 5 & 4.8 \\ \text { 4. Developing technology skills } & 5 & 4.6 \\ \text { 5. Promote development of literacy skills and confidence } & 5 & 4.2 \\ \text { 6. Experiencing multi-media applications } & 5 & 4.4 \\ \text { 7. Experiencing critical analysis of information } & 5 & 3.8 \\ \text { 8. Developing self-reliance within new technology areas } & 4 & 4.1 \\ \text { Scale: } 1=\text { very low, 2=low, 3=neutral, 4=high, 5=very high } & & \end{array}$

Students were also to provide feedback about the podcast project in general and in their own words. Table 2, Student Feedback, includes a sample of their remarks. 
Table 2: Student Feedback

\section{Producing a Podcast}

"I'd like to do more podcasts...maybe do a documentary on a real life topic and sharing with the class. I also learned the value of teamwork."

"The project was really interesting since I never had to do anything like this before. It was a nice break for the daily routine. The process of creating the movie was new and fun."

"I learned a lot by actually going out and talking with a professional in our subject. It was interesting to learn how to find and contact someone knowledgeable in a specific area. I experienced professionalism from the interview."

"I learned a lot about VISTA from our interview. I also learned from hearing other podcasts like the one on video games."

\section{Learning New Software/Technology}

"The media experience was irreplaceable. The programs we learned were new to me. However, now I am now capable of creating a multimedia presentation."

"I learned a lot from some interesting computer programs like MovieMaker. I liked the project because it was challenging."

"It was fun learning the software. It was a goal in of itself. The podcast is an excellent idea as I learned new software and people skills from working within my group and interviewing our expert."

"MovieMaker was easy to learn and use. I also learned about programs that I didn't know existed like Visio and FreeMind."

We considered the project's design in relation to desired learning outcomes described for the MIS course: (1) student understanding of MIS fundamentals; (2) development of analytical and critical thinking; (3) improvement of ethical, interpersonal, communication, and team skills; and (4) instillation of technology skills. As with any project-oriented class that utilizes new technology, it is important not to lose sight of the fact that the purpose is to instill in students knowledge beyond that which is necessary to master the use of technology and software. For this reason, the planning phase of the class project is as critical to the success as the implementation phase. It is during the planning phase that students will learn to define research objectives for their project (business fundamentals), what questions to ask the experts (critical thinking), how to coordinate with others (team work), and learn new technical skills (podcasting). These are desired learning outcomes for the course.

Finally, we considered the design of class projects in relation to the Seven Principles of good practice in undergraduate education: (1) Project design "encourages contact between students and faculty" throughout a series of project benchmarks, (2) Completing the project "develops reciprocity and cooperation among students" through teamwork, (3) Completing the project "encourages active learning' by student defined research objectives, script parameters, background music and other aspects, (4) Project design "gives prompt feedback" through team project schedule, instructor approval of script and final podcast, (5) Completing the project "emphasizes time on task" because instructor provides adequate time to practice important and critical elements for producing a podcast, (6) Project design requires instructor "communicates high expectations" and the belief that students can achieve the high goals set for the class, and (7) Project design "respects diverse talents and different ways of learning from using auditory, visual and hands-on material. 


\section{Conclusion}

A key to the podcast assignment success is placing the technology in the hands of the students themselves and providing adequate guidance. Most students handled the recording work independently, and only a very few technical problems with podcast quality or file format issues were encountered. Many students are familiar with the recording equipment and the editing software was generally easily learned by students.

Another useful strategy is to identify students with experience in using editing software and recording technology. Teams were formed with a goal of balancing the skill level of the teams. In addition, some students expressed interest in specific tasks in producing a podcast such as researching the topic, script writing, interviewing, and editing. A secondary goal in forming teams was to have each team member's interests complement the interest of others on the team.

Lastly, we wanted to provide students with opportunities for creativity in designing their podcast yet keep them on pace to meet the project timeline. We found it valuable to solidify the project timeline by having groups submit periodic progress reports. This provided structure to the project while still allowing students the freedom to explore decision alternatives and options in completing their project.

Podcasts are a creative outlet for students to express ideas, share perceptions and bring experts to the classroom. Some scholars speculate that podcasting may be a harbinger of a new golden age for radio broadcasting via the Internet (Sterne, 2005). One reason producing podcasts may be effective in the classroom is that it can be used in any subject area or course. Given the variety of majors represented in an introductory MIS class, the research topics for projects varied as well. By producing podcasts, students have the opportunity to research, analysis information, communicate effectively and broaden different knowledge areas through their interaction with experts and subsequent dissemination of information in a cutting-edge way. Creating a podcast provides engaging opportunities for students to develop desirable skills as digital storytellers. This also provides the instructor an opportunity to build a library of podcasts which then can be integrated into future classes. The result is a win-win opportunity for student and faculty alike.

Student produced podcasting presents a new opportunity to make students better learners by turning them into knowledge creators.

\section{References}

Atkinson, R. (2006). Podcasting: Do you really need to know? HERDSA News, 28(3). Retrieved July 1, 2009 from http://www.roger-atkinson.id.au/pubs/herdsa-news/28-3.html

Chickering, A. W., \& Gamson, Z. F. (1987). Seven principles for good practice in undergraduate education. AAHE Bulletin, 39(7), 3-7.

Chickering, A. W., \& Gamson, Z. F. (Eds.). (1991). Applying the seven principles for good practice in undergraduate education: New directions for teaching and learning \# 47, 63-69. San Francisco, CA: Jossey-Bass.

Fernandez, V., Simo, P., Sallan, J. M. (2009). Podcasting: A new technological tool to facilitate good practice in higher education. Computers \& Education, 53(2), 385-392.

Henninger, E. A., \& Hurlbert, J. M. (2006). Using the seven principles for good practice in undergraduate education: A framework for teaching cultural diversity in a management course. Journal of Business \& Finance Librarianship, 12(2), 3-15.

Kayes, A. B., Kayes, D. C., \& Kolb, D. A. (2005). Experiential learning in teams. Simulation \& Gaming, $36(3), 330-354$. 
Lee, M. J. W., McLoughlin, C., \& Chan, A. (2008). Talk the talk: Learner-generated podcasts as catalysts for knowledge creation. British Journal of Educational Technology, 39(3), 501-521.

McKeachie, W., (1994). Teaching tips: Strategies, research and theory for college and university teachers. Lexington, Mass.: D. C. Heath and Co.

Miller, D. B. (2006). Podcasting at the University of Connecticut: Enhancing the educational experience. Campus Technology. Retrieved July 1, 2009 from http://campustechnology.com/articles/2006/10/podcasting-at-the-university-of-connecticut-enhancingthe-educational-experience.aspx

Newlin, M. H. \& Wang, A. (2002). Integrating technology and pedagogy: Web instruction and seven principles of undergraduate education. Teaching of Psychology, 29(4), 325-330.

Page, D. \& Mukherjee, A. (2000). Improving undergraduate student involvement in management science and business writing courses using the seven principles in action. Education, 120(3), 547-559.

Passman, R., (2001). Experiences with student-centered teaching in high-stakes assessment environments. Education, 122(1), 189-199.

"Podcast" is the word of the year. (2005). Retrieved July 1, 2009 from http://www.prnewswire.com/cgibin/stories.pl?ACCT=104\&STORY=/www/story/12-05-2005/0004228195

Ritter, M. E., \&Lernke, K. A. (2000). Addressing the seven principles for good practice in undergraduate education with Internet-enhanced education. Journal of Geography in Higher Education, 24(1), 100108.

Sterne, J. (2005). From broad to pod: Histories of transmission for the digital age. Duke University Podcasting Symposium. Retrieved July 1, 2009 from http://isis.duke.edu/events/podcasting/archive.html

Tucker, J., Armstrong, G. \& Massad, V. (2009). Profiling the mind map user: A descriptive appraisal. Journal of Instructional Pedagogies, 2, 1-13. Retrieved July 1, 2009 from http://www.aabri.com/jip.html

Wang, S. (2007). An examination of the introductory MIS course. Journal of Information Technology Education, 6, 135-152. Retrieved from http://www.jite.org/documents/Vol6/JITEv6p135-152Wang203.pdf

\section{Appendix A: Software Sources and Sites}

Audacity Software: http://audacity.sourceforge.net/download/

Audacity tutorial: http://www.how-to-podcast-tutorial.com/17-audacity-tutorial.htm

Dedicated search engines: http://searchenginewatch.com

FreeMind Software: http://sourceforge.net/projects/freemind/

iTunes: http://www.apple.com/itunes/store/podcasts.html

Microsoft Movie Maker for Windows XP: http://www.microsoft.com/windowsxp/downloads/updates/moviemaker2.mspx

Microsoft Movie Maker for Windows Vista: http://www.microsoft.com/downloads/details.aspx?familyid=d6ba5972-328e-4df7-8f9d-068fc0f80cfc

Microsoft Movie Maker tutorial: http://www.windowsmoviemakers.net/Tutorials/HowToMovieMaker.aspx

Microsoft Visio Software: http://www.microsoft.com/downloads/Search.aspx?displaylang=en

Teaching with Blackboard Podcasts http://teachingwithblackboard.niu.edu/blackboard/resources/podcast/

The Teacher's Podcast http://www.podcastforteachers.org/ 


\section{Biographies}

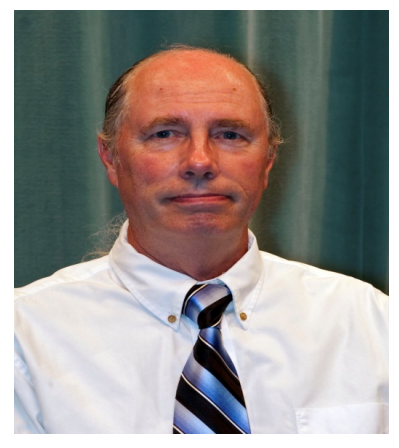

Gary Armstrong is a professor of MIS in the department of accounting and management information systems at Shippensburg University of Pennsylvania. He received his Ed.D. from Temple University. His current research interests include project management, technology in education and information systems analysis and design. He has published papers in journals and proceedings such as Journal of Instructional Pedagogies, Decision Sciences Journal of Innovative Education, Journal of Computer Information Systems and Academy of Business Disciplines Proceedings.

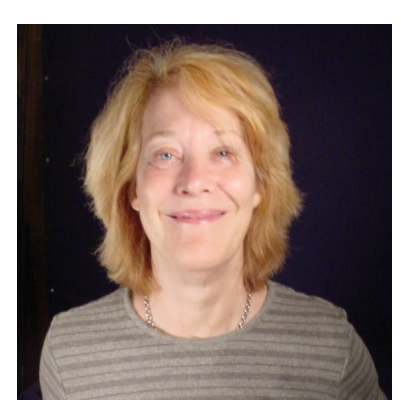

Joanne Tucker is currently an associate professor of supply chain management at Shippensburg University of Pennsylvania. She received her Ph.D. in decision sciences from University of North Texas. Her teaching areas have been supply chain management, purchasing and quantitative analysis. Her research interests include the use of technology in education, pedagogical methods and e-commerce. She has published in various periodicals and proceedings including Journal of Internet Commerce, Quarterly Journal of Electronic Commerce, Journal of Instructional Pedagogies and Decision Science Institute Proceedings.

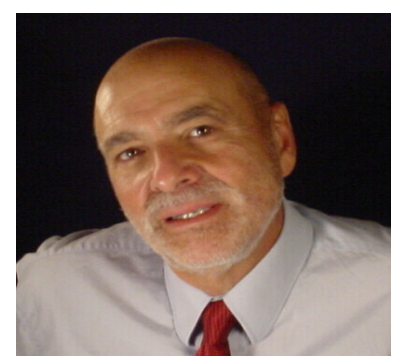

Victor J. Massad earned his doctorate at the University of North Texas. He is currently an associate professor of marketing at Kutztown University and owner of the online retailer auktiononline.com. He specializes in marketing strategy, retailing, e-commerce and sales management. He has published in numerous journals and conference proceedings including the Journal of Internet Commerce, Journal of Marketing Management, American Marketing Association Proceedings and Academy of Marketing Science Proceedings. He also works as a consultant for regional firms in the central Pennsylvania region. His clients include High Industries, S. Clyde Weaver and Daisy Data Display. 